\title{
EKSEKUSI PUTUSAN PENGADILAN TATA USAHA NEGARA TERHADAP PEJABAT PEMERINTAH DAERAH BERDASARKAN UNDANG-UNDANG NOMOR 9 TAHUN 2004
}

\author{
ABDUL TAYIB \\ Dosen Fakultas Hukum Universitas Islam Al-Azhar Mataram \\ e-mail : abdultayib60@gmail.com
}

\begin{abstract}
ABSTRAK
Permasalahan yang di teliti dalam tulisan ini adalah bagaimanakah eksekusi putusan pengadilan tata usaha negara terhadap pejabat pemerintah daerah berdasarkan Undang-Undang Nomor 9 Tahun 2004?.

Pendekatan yang digunakan adalah Pendekatan Perundang-undangan (The Statute Approach) dan Pendekatan Konsep (Conseptual Approach). Hasil penelitian ini menunjukkan bahwa: Proses penyelesaian sengketa Tata Usaha Negara yang merupakan sengketa publik yang melibatkan orang/badan hukum perdata selaku penggugat dan pejabat pemerintah (Pejabat TUN) selaku tergugat, kekuatan hukum putusan eksekusi pengadilan Tata Usaha Negara yang merupakan pelaksana kekuasaan kehakiman di lingkungan Mahkamah Agung setara dengan keputusan pada badan peradilan lainnya. Kemudian perubahan normatif Peradilan Tata Usaha Negara dengan Undang-Undang Nomor 9 Tahun 2004 Tentang Perubahan Atas Undang-Undang Nomor 5 Tahun 1986 Tentang Peradilan Tata Usaha Negara menjadikan upaya hukum yang terdapat dalam Pasal 116 seperti uang paksa dan/atau sanksi administratif dan publikasi putusan pengadilan menjadi lebih baik ketimbang menggunakan model eksekusi secara hierarkis yang dianggap tidak efektif dengan adanya era otonomi daerah sekarang. Dengan keadaan tersebut masih harus diupayakan memberikan alternatif lain untuk menghasilkan efek jera bagi pejabat pemerintah khususnya pejabat pemerintah daerah untuk tunduk pada Putusan Pengadilan Tata Usaha Negara.
\end{abstract}

Kata kunci : Pengadilan Tata Usaha Negara, Pejabat Pemerintah

\section{ABSTRACT}

The problem examined in this paper is how is the execution of state administrative court decisions against regional government officials based on Law Number 9 of 2004?

The approach used is the statutory approach (The Statute Approach) and the conceptual approach (Conceptual Approach). The results of this study indicate that: The process of resolving State Administration disputes which are public disputes involving persons / civil legal entities as plaintiffs and government officials (TUN Officials) as defendants, the legal power of the decision to execute the State Administrative Court which is the executor of judicial power in the environment. The Supreme Court is equivalent to decisions of other judicial bodies. Then the normative changes to the State Administrative Court with Law Number 9 of 2004 concerning Amendments to Law Number 5 of 1986 concerning State Administrative Courts made legal remedies contained in Article 116 such as forced money and/or administrative sanctions and publication of court decisions. be better than using a hierarchical execution model which is considered ineffective in the current era of regional autonomy. Under these circumstances, efforts must be made to provide other alternatives to produce a deterrent effect for government officials, especially local government officials, to submit to the State Administrative Court's decision.

Keywords: State Administrative Court, Government Officials

\section{PENDAHULUAN}

Indonesia ialah negara hukum yang menganut Konsep Negara Kesejahteraan (Walfer State), sebagaimana tertuang dan diisyaratkan dalam alinea keempat Pembukaan UUD 1945 yang merupakan landasan tujuan didirikannya negara. Realisasi terhadap tujuan negara tersebut dilakukan melalui proses pembangunan secara bertahap, berlanjut, dan berkesinambungan, sehingga sebagai konsekuensi dari itu 
pemerintah berperan aktif dalam melaksanakan tugas pembangunan dan tugas service publik (bestuurzorg). Dalam konsep negara kesejahteraan Indonesia, pemerintah selaku pihak yang diberi wewenang yang luas untuk turut serta dalam kehidupan masyarakat yang implikasinya mewujudkan pada kesejahteraan umum dengan berlandaskan pada Idiologi Pancasila.

Keputusan yang merupakan pranata tindakan pemerintah adalah salah satu instrument yuridis yang sering digunakan pemerintah dalam melakukan hubungan kepada masyarakat. Di antara keputusan tersebut ada yang di sebut dalam arti beschikking.

Menurut Paulus Effendi Lotulung (1993) diperlukannya syarat-syarat baik formal dan materil untuk sahnya beschikking. Oleh karena itu, masing-masing syarat sebagai berikut :

1. Syarat-Syarat Formal :

a. Syarat-syarat yang ditentukan berhubung dengan persiapan dibuatnya keputusan dan berhubung dengan cara dibuatnya keputusan harus dipenuhi ;

b. Harus diberi bentuk yang telah ditentukan;

c. Syarat-syarat yang berhubungan dengan pelaksanaan keptusan itu harus dipenuhi;

d. Jangka waktu harus ditentukan antara timbulnya hal-hal yang menyebabkan dibuatnya dan diumumkannya keputusan itu, dan tidak boleh dilupakan.

2. Syarat-Syarat Materil :

a. Alat pemerintahan yang membuat keputusan itu harus berwenang (berhak);

b. Dalam kehendak alat pemerintahan yang membuat keputusan itu tidak boleh ada kekurangan yuridis, yaitu tidak boleh ada paksaan (dwang), kekeliruan (dwaling), dan penipuan (bedrog);

c. Keputusan itu harus mengandung kebenaran tentang fakta-faktanya dan tidak boleh ada kekeliruan hukum;

d. Isi dan tujuan keputusan itu harus sesuai dengan isi dan tujuan yang hendak dicapai (doelmatig) dan tidak mengandung detournement de pourvoir.

Keputusan-keputusan pejabat pemerintah (Pejabat Tata Usaha Negara) yang menimbulkan kerugian di pihak warga negara merupakan dasar sengketa antara pejabat pemerintah dan warga negara, maka dibentuklah Peradilan Tata Usaha Negara dengan mengundangkan Undang-Undang Nomor 5 Tahun 1986 Tentang Peradilan Tata Usaha Negara. Peradilan ini berfungsi untuk menilai dan menetukan apakah suatu keputusan-keputusan yang diterbitkan oleh pejabat bertentangan dengan hukum atau tidak sah sebagai kompetensi absolut dari Peradilan Tata Usaha Negara.

Pemerintahan Negara Kesatuan Republik Indonesia terdiri dari Pemerintah dan Pemerintahan Daerah sebagai wujud implementasi dari berkembangnya jiwa semangat pemberlakuan otonomi daerah pasca reformasi. Hal ini membawa konsekuensi daerah khususnya Kabupaten/Kota diberikan kewenangan yang seluas-luasnya untuk mengelola daerahnya secara mandiri tanpa harus bergantung adanya intervesi dari pemerintah (Pusat) dan sebagai akibatnya Kabupaten/Kota yang menjadi titik konsentrasi pelaksanaan otonomi daerah tidak lagi bertanggung jawab kepada pemerintahan atasan meskipun diantaranya ada hubungan. Hal ini merupakan dari perubahan Pasal 18 Undang-Undang Dasar 1945 yang dapat dikatakan sebagai bentuk perlawanan terhadap sistem penyelenggaraan Pemerintahan Daerah yang sebelumnya sentralistik dan otoriter menuju kearah yang desentralistik dan demokratis. Perubahan ini secara terang dan nyata tercantum dalam konsideran Undang-Undang Nomor 32 Tahun 2004 Tentang Pemerintahan Daerah yang menetukan :

"Bahwa dalam rangka penyelenggaraan Pemerintahan Daerah sesuai dengan amanat Undang-Undang Dasar 1945, pemerintah daerah, yang mengatur dan mengurus sendiri urusan pemerintahan menurut asas otonomi dan tugas pembantuan, diarahkan untuk mempercepat terwujudnya kesejahteraan masyarakat melalui peningkatan, peningkatan daya saing daerah dengan memperhatikan prinsip demokrasi, pemerataan, keadilan, keistimewaan dan kekhususan suatu daerah dalam sistem Negara Kesatuan Republik Indonesia". Pemerintah Daerah dalam konteks kekinian harus tetap dimaknai sebagai bagian dari integral negara Indonesia bukan ditafsirkan sebagai bagian terpisah dari negara Indonesia. Meskipun pemerintah daerah sebagai salah satu unsur pelaksana pemerintahan daerah tidak lagi mempertanggungjawabkan perbuatannya kepada pemerintah atasan, akan tetapi tetap berprinsip bahwa kekuasaan yang selama ini dipegang olehnya merupakan dari rakyat yang tidak boleh di sia-siakan.

Tetapi dengan kondisi sebagaimana dimaksud di atas malahan menjadikan Pejabat Pemerintah (Pejabat Tata Usaha Negara Daerah) dalam melaksanakan tugasnya seringkali terbentur dengan sikap warga masyarakat yang menilai tindakan pemerintah dalam bentuk keputusan yang berlaku kepada warga masyarakat merugikannya. Hal ini dapat dilihat pada banyaknya gugatan yang didaftar pada Pengadilan Tata Usaha Negara untuk diuji apakah tindakan tersebut telah melalui tahapan-tahapan dalam peraturan dasarnya untuk menilai sah atau tidaknya penggunaan wewenang pemerintah menurut hukum publik. Dan apabila 
tindakan pejabat pemerintah di daerah (Pejabat TUN) dinyatakan kalah oleh Pengadilan Tata Usaha Negara, sebagai tindakan lebih lanjut (follow up) dilaksanakan eksekusi.

Eksekusi yang lebih menyadarkan pada kesadaran tergugat (eksekusi otomatis) atau dengan peneguran berjenjang secara hierarki (floating norm) sebagaimana diatur dalam Pasal 116 UU Nomor 5 Tahun 1986 Tentang Peradilan Tata Usaha Negara ternyata tidak cukup efektif mempunyai daya paksa terhadap Pejabat Pemerintah (Pejabat Tata Usaha Negara) melaksanakan putusan hakim Peradilan Tata Usaha Negara yang telah memperoleh kekuatan hukum tetap (inkracht van gewijsde). Oleh karena itu, pemberlakuan uang paksa (dwangsomlastrainte) dan sanksi administrasi serta publikasi putusan hakim diatur dalam Pasal 116 UndangUndang Nomor 9 Tahun 2004 Tentang Perubahan Undang-Undang Nomor 5 Tahun 1986 Tentang Peradilan Tata Usaha Negara membawa harapan sekaligus mengurangi pesimisme masyarakat selaku pencari keadilan dalam sengketa administrasi terhadap eksistensi Peradilan Tata Usaha Negara sebagai lembaga kontrol terhadap pemerintah sekaligus sebagai perlindungan hukum bagi masyarakat.

Selain itu, pelaksanaan eksekusi terhadap Pejabat Pemerintah (Pejabat Tata Usaha Negara) khususnya pejabat pemerintah di daerah terkendala dengan adanya Otonomi Daerah yang menyebabkan daerah tidak lagi mempunyai tanggung jawab terhadap pemerintah atasan. Meskipun Undang-Undang Nomor 32 Tahun 2004 mengatur hubugan antara Pemerintah Daerah dengan Pemerintah (Pusat) dan antara pemerintah daerah lainnya, akan tetapi sifat hubungannya hanya koordinasi belaka. Ditambah lagi permasalahan teknis yuridis eksekusi sendiri yang belum ada pengaturan lebih lanjut berupa produk hukum tentang pelaksanaan eksekusi pada Pasal 116 Undang-Undang Nomor 9 Tahun 2004 Tentang Perubahan Undang-Undang Nomor 5 Tahun 1986 Tentang Peradilan Tata Usaha Negara.

Sehingga dalam pelaksanaan follow up putusan Pengadilan Tata Usaha Negara Daerah mulai ada jarak antara "das sain" dan "das sollen" yang dapat menggangu pelaksanaan kegiatan pemerintah menurut hukum modern yang sejak lama telah dicita-citakan oleh founding father kita. Hal ini demi mengantisipasi hambatan semakin banyaknya Pejabat Tata Usaha Negara khususnya Pejabat Tata Usaha Negara di daerah yang tidak patuh terhadap putusan Pengadilan. Agar norma-norma khusus yang di introdusir dalam UndangUndang Nomor 9 Tahun 2004 Tentang Peradilan Tata Usaha Negara tidak dianggap menjadi norma yang gagal.

\section{Rumusan Masalah}

Berdasarkan latar belakang di atas yang hendak diteliti oleh penulis yakni "Bagaimanakah eksekusi putusan pengadilan tata usaha negara terhadap pejabat pemerintah daerah berdasarkan undang-undang nomor 9 tahun 2004?"

\section{Tujuan Penelitian}

Berdasarkan rumusan masalah di atas maka tujuan penelitian ini yaitu untuk mendeskripsikan eksekusi putusan pengadilan tata usaha negara terhadap pejabat pemerintah daerah berdasarkan undang-undang nomor 9 tahun 2004?

\section{METODE PENELITIAN}

Penelitian ini merupakan penelitian hukum normatif yaitu dengan mengkaji/ menganalisis bahan hukum primer dan bahan hukum sekunder dengan memahami hukum sebagai seperangkat peraturan atau norma-norma positif di dalam sistem perundang-undangan yang mengatur berkaitan dengan masalah yang diteliti. Dengan jenis pendekatan perundang-undangan (the statute approach) dan pendekatan konsep (conseptual approach).

\section{HASIL DAN PEMBAHASAN}

Pelaksanaan Eksekusi Hierarkis Dalam Pasal 116 Undang-Undang Nomor 9 Tahun 2004 Tentang Perubahan Atas Undang-Undang Nomor 5 Tahun 1986 Dalam Kaitannya Dengan Otonomi Daerah.

Hubungan Pemerintah Pusat dan Daerah dalam kaitanya dengan pembagian kewenangan merupakan sesuatu yang banyak diperbincangkan. Sebagai salah satu fenomena pasca reformasi, kewenangan pusat dan daerah yang diikat dalam bingkai negara kesatuan seringkali menimbulkan upaya tarik menarik antara kedua satuan pemerintahan yang berbeda. Terlebih lagi pemerintah sangat memegang kendali atas berbagai urusan pemerintahan yang sepertinya tidak mau diserahkan sepenuhnya kepada daerah untuk mengurusnya.

Penyerahan urusan pemerintahan dari pemerintah kepada daerah otonomi khususnya titik konsentrasinya pada Kabupaten/Kota sebagai satuan pemerintahan yang lebih rendah melalui desentralisasi 
dengan asas otonomi dan tugas pembantuan, tidak serta merta menjadikan persoalan pembagian urusan pemerintahan menjadi terselesaikan. Banyak urusan-urusan pemerintahan yang belum tergambarkan secara jelas tentang kedudukan dan kewenangannya apakah berada pada Pusat, Provinsi atau Kabupaten/Kotamadya menyebabkan benturan-benturan kewenangan antar satuan pemerintahan.

Pelaksanaan urusan pemerintahan baik dalam bentuk desentralisasi, baik dekonsentrasi dan tugas pembantuan (medebewind) menjadi sangat penting untuk menentukan kejelasan kewenangan Pejabat Tata Usaha Negara dalam lingkup pemerintahan mana yang berwenang (Kabupaten/Kotamadya, Provinsi maupun Pusat) untuk melakukan tindakan hukum khususnya pada tindakan mengeluarkan Keputusan Tata Usaha Negara. Hal ini menjadi sangat penting apabila dikemudian hari tindakan-tindakan hukum (bestuurhandeling) dari Pejabat Tata Usaha Negara dalam bentuk beschikking menjadi sengketa yang diperiksa, di putus dan diselesaikan di Peradilan Tata Usaha Negara. Dari produk tindakan pemerintah (beschikking) tentunya tidak dapat dilepaskan dari Peraturan Perundang-undangan yang menjadi landasan yuridis. Ini merupakan konsekuensi dari pelaksanaan negara hukum yang menjadikan asas Legalitas (spesialiteit beginsel) menjadi primadonanya.

Dengan adanya desentralisasi yang merupakan pemencaran kekuasaan dengan bertumpu pada teori model mitra (partnership model) menjadikan antara pemerintah dengan daerah otonomi tidak lagi hierarkis layaknya pada waktu pelaksanaan Undang-Undang Nomor 5 Tahun 1974 Tentang Pokok-Pokok Pemerintah Daerah. Meskipun dengan penerapan teori ini tidak menjadikan daerah seolah-olah sejajar dengan pusat tetapi tetap merupakan bagian dari integral pemerintah secara keseluruhan sebagai pelaksana urusan pemerintahan setelah dikurangi urusan legislatif yang dilaksanakan oleh Parlemen dan Yudikatif oleh Kekuasaan Kehakiman (Mahkamah Agung dan Mahkamah Konstitusi).

Persoalan tentang kewenangan yang belum jelas antara Pusat dan Daerah menimbulkan stigma negatif bahwa pusat masih setengah hati untuk menyerahkan sebagian urusan-urusan yang dahulu berada di pusat, hal ini merupakan permasalahan tersendiri pasca reformasi khususnya yang berkaitan dengan sumber-sumber kewenangan baik melalui atribusi, delegasi, dan mandat.

Benturan kewenangan pada umumnya disebabkan oleh adanya konflik kepentingan yang lahir dan melekat dalam suatu kewenangan, termasuk yang terpaut dengan kepentingan akan hak dan pengelolaan dana publik. Sifat kewenangan melalui sumber atribusi, delegasi, dan mandat merupakan tolok ukur utama dalam menentukan Pejabat Pemerintah (Pejabat Tata Usaha Negara) yang berwenang dalam mengeluarkan Keputusan Tata Usaha Negara. Manakala Keputusan Tata Usaha Negara yang dikeluarkan Badan/Pejabat Tata Usaha Negara dalam kaitannya dengan bestuurdarden Pemerintah Daerah, maka pertanggung jawaban Administratif rechtelijke bersifat atribusi. Tatkala kewenangan mengeluarkan Keputusan Tata Usaha Negara bermasalah diperoleh dengan cara delegasi maka Pejabat/Badan yang dimaksud tetap bertanggung jawab selaku penerima delegasi. Dalam hal ini pemerintah kehilangan kewenangan yang telah didelegasikan. Ciriciri pendelegasian mirip dengan Desentralisasi (Marzuki, 2003).

Menurut Supriana bahwa badan/Pejabat Tata Usaha Negara yang Keputusan Tata Usaha Negara dalam kaitannya penyelenggaraan tugas-tugas Dekonsentrasi, bertanggung jawab secara mandatum. Badan/Pejabat yang bersangkutan bertindak mewakili Pemerintah Pusat dan/atau Perangkat Pusat yang ditempatkan di Daerah selaku mandat (mandator) justru bertanggung jawab terhadap perbuatan Keputusan (beschikking) itu. "sedangkan Keputusan Tata Usaha Negara yang dikeluarkan Badan/Pejabat Tata Usaha Negara dalam kaitan dengan tugas pembantuan bertanggung jawab secara mandatum. Pemberi tugas turut serta bertanggung jawab atas tindakan dan pemberian mandat”.

Dalam Undang-Undang Nomor 32 Tahun 2004 Tentang Pemerintahan Daerah telah mencantumkan secar jelas mana urusan Pemerintah Daerah baik Provinsi dan Kabupaten/Kota. Dalam artian kata bahwa urusan pemerintah yang menjadi urusan pemerintah pusat dalam Pasal 10 tidak boleh ada ikut campur Pemerintah Daerah. Dengan kata demikian urusan pemerintah diluar Pasal 10 Undang-Undang Nomor 32 Tahun 2004 Tentang Pemerintahan Daerah menjadi urusan Otonomi Daerah. Meskipuan demikian berdasarkan ajaran rumah tangga secar riil yang merupakan alternative jalan tengah (middle range) antara ajaran rumah tangga formil dan materil yang merupakan jalan keluar dari permasalahan benturan-benturan kewenangan antara Pemerintah Daerah. Menurut Bagir Manan. "Ajaran rumah tangga formil adalah suatu tatanan pembagian wewenang, tugas dan tanggung jawab antara pusat dan daerah untuk mengatur dan mengurus pemerintahan yang tidak ditetapkan secara rinci”. Sedangkan ajaran rumah tangga materil pembagian tugas, wewenang dan tanggung jawab antara pusat dan daerah ditentukan secara pasti atau limitif dan terperinci dari dalam Peraturan Perundang-undangan yang menjadi pembentukan daerah.

Dalam hal telah ada pembagian urusan kewenangan dalam Peraturan Perundang-undangan tetapi dalam pelaksanaannya masih banyak menimbulkan masalah yang menyebabkan ketidakharmonisan antara pusat dan daerah. Hal ini dapat mengulang kembali kejadian tersebut seperti pada masa-masa dahulu dengan pola pemerintahan yang masih sentralistik. Dengan demikian, produk hukum berupa Keputusan Tata Usaha 
Negara yang diterbitkan oleh Pejabat Tata Usaha Negara di Daerah akan menjadi sebuah problematika tersendiri tatkal Keputusan Tata Usaha Negara yang menjadi sengketa di Peradilan Tata Usaha Negara yang dikeluarkan dengan Peraturan Perundang-undangan telah dinyatakan tidak sah sehingga dilaksanakannya putusan dengan model eksekusi secara hierarkis.

Sehubungan dengan pelaksanaaan eksekusi putusan yang tercantum dalam Pasal 116 Undang-Undang Nomor 9 Tahun 2004 yang telah mengandung upaya paksa masih terkendala dengan belum adanya aturan pelaksana tentang eksekusi putusan Pengadilan, sehingga eksekusi hierarkis yang terdapat dalam UndangUndang Nomor 5 Tahun 1986 jiwanya masih ada, yang akan memungkinkan Hakim Peradilan Tata Usaha Negara untuk menerapkan sebagai alternative pengganti upaya paksa yang belum ada aturan pelaksana.

Akan tetapi pelaksanaan eksekusi hierarkis pada Undang-Undang Nomor 5 Tahun 1986 Tentang Peradilan Tata Usaha Negara untuk diterapkan pada Undang-Undang Nomor 5 Tahun 1976 Tentang PokokPokok Pemerintah Daerah tidak akan menimbulkan masalah berarti mengingat masih adanya pola jenjang hierarki pemerintah antara Pusat dan Daerah. Dimana Presiden menduduki sebagai pemegang kendali satuan pemerintahan tertinggi yakni Pemerintah Pusat sehingga mudah melaksanakan model eksekusi hierarkis. Namun, setelah berlakunya Undang-Undang Nomor 22 Tahun 1999 dan sekarang dengan Undang-Undang Nomor 32 Tahun 2004 Tentang Pemerintahan Daerah menyebabkan eksekusi hierarkis menjadi masalah. Meskipun Pemerintah dan Pemerintahan Daerah mempunyai hubungan tetapi tidak serta merta pelaksanaan eksekusi hierarkis menjadi mudah. Penyebab eksekusi hierarkis sangat sulit diterapkan sekarang ini khususnya pada Pejabat Tata Usaha Negara Daerah disebabkan pada Undang-Undang Nomor 9 Tahun 2004 Tentang Perubahan Atas Undang-Undang Nomor 5 Tahun 1986 belum banyak memberikan penyelesaian dengan perubahan system Pemerintahan Daerah yang berlandaskan pada Desentralisasi (asas otonomi dan asas pembantuan) yang berarti adanya penyerahan urusan pemerintahan yang diatur secara bebas dan mandiri terlepas dari intervensi dan pengaruh pusat.

Hal ini mengingat Undang-Undang Nomor 9 Tahun 2004 disahkan pada tanggal 29 Oktober 2009 sebelum berlakunya Undang-Undang Nomor 32 Tahun 2004 Tentang Pemerintahan Daerah.

Dengan demikian pelaksanaan eksekusi hierarkis akan terus dimungkinkan dalam pelaksanaan otonomi daerah sekarang ini sepanjang pelaksanaan dengan konsep upaya paksa sebagaimana yang telah tercantum dalam Pasal 116 Undang-Undang Nomor 9 Tahun 200 Tentang Perubahan Atas Undang-Undang Nomor 5 Tahun 1986 Tentang Peradilan Tata Usaha Negara belum ada aturan pelaksananya. Akan tetapi kelemahan dari eksekusi hierarkis terletak pada tidak adanya sanksi secara tegas dari Presiden sebagai pucuk dari Pemerintahan Tertinggi berdasarkan Pasal 4 ayat (1) Amandemen UUD 1945 melainkan hanya berupa peneguran kepada tergugat untuk melaksanakan putusan pengadilan tanpa sebuah instrument yang dapat dipatuhi oleh pemerintah daerah khususnya pejabat Tata Usaha Negara Daerah. Sehingga pelaksanaan eksekusi selama ini hanya disandarkan pada kesadaran moral tergugat untuk melaksanakan putusan pengadilan secara sukarela.

\section{Eksekusi Putusan Tata Usaha Negara Setara Dengan Putusan Pengadilan Lainnya.}

Secara filosofis putusan mengandung makna pelaksana putusan oleh atau dengan bantuan pihak lain yang bersangkutan. Sedangkan hakikat eksekusi tidak lain merupakan realisasi daripada kewajiban pihak yang bersangkutan utuk memenuhi kewajibannya sesuai dengan yang tercantum dalam amar putusan.

Setiap putusan pengadilan mencantumkan frasa "DEMI KEDAILAN BERDASARKAN KETUHANAN YANG MAHA ESA" yang mengharuskan para pihak untuk tunduk dan taat melaksanakan putusan pengadilan. Hal ini sebagai akibat timbulnya paham dalam doktrin ilmu hukum bahwa kedudukan Hakim sebagai Wakil Tuhan di dunia yang mengatas namakan keadilan demi memutus perkara yang diperhadapkan kepadanya. Sehingga mengindikasi bahwa peranan kedaulatan Tuhan dalam negara Indonesia serta dengan kedaulatan-kedaulatannya.

Dengan bertitik tolak pada setiap putusan wajib mencantumkan frasa "DEMI KEDAILAN BERDASARKAN KETUHANAN YANG MAHA ESA" memberikan kemungkinan keempat pilar peradilan dalam lingkungan Mahkamah Agung yang kesemuanya sebagai pelaku Kekuasaan Kehakiman mempunyai kedudukan yang sejajar pada institusi lembaganya. Hal ini memberikan sebuah kesetaraan tanpa harus memberikan pola-pola yang tidak sejajar pada putusan pengadilan sehingga antara kedudukan peradilan yang satu dengan yang lainnya berbeda.

Itulah sebabnya, suatu putusa hakim yang diucapkan dalam persidangan terbuka untuk umum merupakan sebuah putusan hukum, lazim juga dinamakan judiciele berlissing. Kepatuhan akan putusan hakim khususnya Hakim Pradilan Tata Usaha Negara dalam mengadili sebuah sengketa publik tidak lain kepatuhan Badan atau Pejabat Tata Usaha Negara akan hukum (law abiding) (Supandi, 2004).

Sebagai konsekuensi dari negara hukum maka peradilan melalui putusan-putusannya dijadikan sebagai tempat terakhir the last resort (mencari kebenaran dan keadilan) sehingga pengadilan masih diandalkan 
sebagai badan hukum yang yang berfungsi menegakkan kebenaran dan keadilan (to enforce the truth and to enforce justice). Serta pengadilan sebagai katup penekan atau "pressure valve" atas segala pelanggaran hukum, ketertiban masyarakat dan pelanggaran ketertiban umum (Harahap, 1997).

Sebelum adanya perubahan eksekusi pada Undang-Undang No. 9 Tahun 2004 Tentang Perubahan atas Undang-Undang Nomor 5 Tahun 1986 Tentang Peradilan Tata Usaha Negara, maka pelaksanaan eksekusi dititikberatkan pada kesadaran hukum pejabat itu sendiri. Dengan bersandar pada eksekusi hierarki yang memberikan efek kepatuhan kepada pejabat pemerintah dengan melakukan peneguran yang melibatkan atasannya maupun hingga sampai kepada Presiden.

Campur tangan Presiden sebagai pemegang kekuasaan pemerintah tertinggi dalam eksekusi putusan Pengadilan Tata Usaha Negara secara hierarkis memang diperlukan mengingat eksekusi pada pengadilan tersebut tidaklah semudah dalam pelaksanaan eksekusi badan Peradilan Umum (Perdata maupun Pidana). Dari konsekuensi tersebut Presiden bertanggung jawab terhadap pembinaan Pegawai Negeri/Aparatur Pemerintah yang pelaksanaannya didelgasikan kepada menterinya dalam hal ini adalah Menteri Pendayagunaan Aparatur Negara, tentunya Presiden juga bertanggung jawab agar setiap aparatur Pemerintah dapat mentaati semua Peraturan Perundang-undangan yang berlaku termasuk mentaati putusan pengadilan dengan prinsip nengara hukum yang dianut Indonesia.

Secara Yuridis meskipun Ketua Pengadilan Tata Usaha Negara telah mengajukan permintaan terhadap Presiden sebagai pemegang kekuasaan pemerintahan tertinggi untuk melaksanakan putusan Pengadilan apabila proses peneguran melalui instansi atasan dan tergugat tidak berhasil, tidak ada bahwa konsekuensi maupun sanksi hukum dari Presiden yang akan diberikan kepada Pejabat Pemerintah yang tidak melaksanakan secara sukarela. Disini Presiden hanya dibayang-bayangi akan sanksi moral untuk mewujudkan kegiatan pemerintahan yang bersih (clean government) dan berwibawa.

Dengan memasukkan upaya paksa pada perubahan Undang-Undang Nomor 5 Tahun 1986 Tentang Peradilan Tata Usaha Negara dengan mengundangkan Undang-Undang Nomor 9 Tahun 2004 Tentang Perubahan Atas Undang-Undang Nomor 5 Tahun 1986 khususnya Pasal 116 yang mengatur tentang eksekusi maka setiap putusan Pengadilan Tata Usaha Negara bisa menjadi tolok ukur/patokan kepatuhan pejabat akan putusan pengadilan. Bukan hanya persoalan tentang kalah menangnya para pihak akan tetapi lebih dipandang sebagai langkah korektif Pengadialan Tata Usaha Negara terhadap tindakan pemerintah yang selama ini dinilai kebanyakan selalu merugikan warga masyarakat.

Upaya paksa menjadikan Peradilan Tata Usaha Negara dengan putusan-putusannya sama kualitasnya dengan putusan-putusan badan peradilan lainnya yang mengandung penghukuman (eksekusi) terhadap yang kalah. Hal ini terletak pada amar putusan yang berisi tentang perintah melakukan kewajiban. Manakala ada Pejabat Pemerintah yang secara terang-terangan melakukan tindakan untuk tidak patuh dan taat pada perintah hakim. Maka sesungguhnya Pejabat Pemerintah tersebut tidak layak untuk duduk pada satu jabatan. Disebabkan secara normatif eksekusi putusan Hakim Peradilan Tata Usaha Negara lebih menyadarkan pada konsekuesi kerelaan pejabat yang bersangkutan untuk melaksanakannya. Sehingga budaya hukum (legal culture) taat pada putusan pengadilan khususnya Pengadilan Tata Usaha Negara wajib digalakkan pada lingkungan pejabat pemerintah ogar konsep negara hukum tercapai dinegara ini.

Dengan demikian diperlukan sikap kosisten aparatur pemerintah maupun aparat penegak hukum lainnya dalam mensejajarkan sebagai penghambatan hukum. Bukannya sebagai yang mengendalikan hukum dengan sesukan hati demi mencapai suatu tujuan kepentingan kelompok tertentu maupun penguasa.

\section{Eksekusi Putusan Tata Usaha Negara Terbatas Pada Batal/Tidaknya Keputusan Tata Usaha Negara.}

Pada dasarnya eksekusi putusan Pengadilan Tata Usaha Negara yang menyatakan batal/tidak sahnya Keputusan Tata Usaha Negara yang menjadi pangkal sengketa merupakan kompetesi absolut Peradilan Tata Usaha Negara. Keputusan Tata Usaha Negara disini diartikan merupakan tindakan pemerintah yang mempunyai akibat hukum pada orang atau badan hukum perdata yang norma pemberlakuannya adalah konkret individual, dan final bukanlah Keputusan Tata Usaha Negara yang bersifat abstrak dan umum.

Berangkat pada ketentuan Pasal 53 ayat (1) Undang-Undang Nomor 51 Tahun 2009 Tentang Perubahan Kedua atas Undang-Undang Nomor 5 Tahun 1986 Tentang Peradilan Tata Usaha Negara yang merupakan dasar alasan untuk mengajukan gugatan dengan mencantumkan secara tegas tentang batal/tidak sahnya Keputusan Tata Usaha Negara yang harus di muat dalam petitum surat gugatan.

Hal ini berarti tidak semua Keputusan Tata Usaha Negara yang terbukti cacat hukum pada waktu proses persidangan hanya bisa dinyatakan tidak sah. Akan tetapi secara yuridis Keputusan Tata Usaha Negara yang digugat ke Pengadilan diyatakan batal. Apa bila ini terjadi, hakim akan diperhadapkan pada permasalahan tentang eksekusi dengan pilihan mana keputusan Tata Usaha Negara yang diterbitkan oleh tergugat apakah diyatakan batal ataupun tidak sah. Selain itu hakim juga harus dituntut memperhatikan secara seksama kemungukinan yang akan terjadi ada atau tidak hal-hal yang akan dilakukan tindak lanjut 
oleh tergugat sebagai pihak yang dikalahkan setelah putusan pengadilan memperoleh kekuatan hukum tetap berupa kewajiban-kewajiban tertentu.

Dengan berangkat pada Pasal 115 UU No. 5 Tahun 2004 Tentang Perubahan Atas UU No. 5 Tahun 1986 Tentang Peradilan Tata Usaha Negara yang menentukan:"Hanya Putusan Pengadilan yang telah memperoleh kekuatan hukum tetap yang dapat dilaksanakan" maka perlu ditetapkan adanya kewajibankewajiban sebagaimana yang dimaksud pada Pasal 97 ayat (9) huruf a dan b Undang-Undang Nomor 5 Tahun 1986. Sehingga Keputusan Tata Usaha Negara yang disengketakan relevan apa bila hakim menyatakan tidak sah. Dengan demikian Keputusan Tata Usaha Negara dinyatakan batal dalam amar putusan tidak perlu lagi adanya tindak lanjut (follow up) berupa kewajiban apa saja yang harus dilakukan oleh tergugat setelah putusan Pengadilan Tata Usaha Negara memperoleh kekuatan hukum tetap.

Untuk putusan batal memang tidak memerlukan eksekusi, karena dengan peradilan menyatakan batal, maka Keputusan Tata Usaha Negara yang menjadi sengketa yang setelah putusan pengadilan memperoleh kekuatan hukum tetap saat itu juga baik tindakan hukum tergugat maupun akibat yang ditimbulkan pada tindakannya diimplementasikan serta dijabarkan dalam bentuk Keputusan Tata Usaha Negara dianggap menurut hukum tidak pernah ada. Sehingga nantinya akan kembali pada posisi semula keadaannya sebelum penerbitan Keputusan Tata Usaha Negara.

Adanya tenggang waktu yang cukup lama pada proses pelaksanaan eksekusi putusan Pengadilan Tata Usaha Negara yang memerlukan tindakan sebagaimana dimaksud dalam Pasal 97 ayat (9) huruf a dan b UU No. 5 Tahun 1986 Tentang Peradilan Tata Usaha Negara untuk Keputusan Tata Usaha Negara yang dinyatakan tidak sah merupakan salah satu hambatan. Hambatan itu dapat terjadi pada putusan pengadilan yang telah memperoleh kekuatan hukum tetap tetapi tergugat tidak mau segera patuh mencabut Keputusan Tata Usaha Negara yang bersangkutan. Dalam arti kata bertindak diam saja dalam merealisasikan eksekusi putusan Pengadilan sehubungan dengan amar putusan yang mewajibkan tergugat melaksanakan putusan pengadilan menurut Pasal 116 UU No. 5 Tahun 1986 Tentang Peradilan Tata Usaha Negara. Keadaan ini akan mengakibatkan pada ketidakpastian hukum dan bertentangan pada hukum acara yang berlaku pada semua lingkungan peradilan pada Mahkamah Agung yakni Peradilan cepat, sederhana dan biaya ringan.

\section{Upaya Hukum Dalam Undang-Undang Peradilan Tata Usaha Negara.}

Pelaksanaan upaya paksa dalam eksekusi putusan Pengadilan Tata Usaha Negara dilatarbelakangi oleh sistem putusan yang masih lemah. Sistem yang masih menitikberatkan pelaksanaan eksekusi putusan pengadilan yang memperoleh kekuatan hukum tetap diserahkan kewenangan sepenuhnya kepada tergugat/terhukum untuk sukarela dan ikhlas melaksanakan isi putusan.

Ketiadaan upaya paksa pada UU No. 5 Tahun 1986 Tentang Peradilan Tata Usaha Negara mempunyai relevansi hukum terhadap eksekusi putusan yang sangat bergantung pada niat baik dari Pejabat Tata Usaha Negara itu sendiri yang dalam pelaksanaan diserahkan kepada Pejabat Tata Usaha Negara bersangkutan.

Sehingga karena pelaksanaan eksekusi diserahkan sepenuhnya wewenang tersebut kepada Pejabat Tata Usaha Negara yang bersangkutan untuk melaksanakannya yang mengakibatkan pencari keadilan tidak mendapatkan kepastian hukum. Kepastian hukum itu akan timbul apabila Pejabat Tata Usaha Negara yang dihukum untuk melaksanakan putusan pengadilan tidak bersedia secara sukarela melaksanakan sesuai dengan isi amar putusan pengadilan. Ketidakrelaan tersebut dapat juga berakibat pada kewibawaan dan eksistensi Peradilan Tata Usaha Negara di mata warga masyarakat sebagai salah satu badan peradilan yang diharapkan pembentukannya dengan tujuan melakukan tindakan kontrol secara represip terhadap produk hukum pemerintah berupa beschikking yang dikeluarkan berdasar wewenang secara tertulis dalam Peraturan Perundang-undangan.

Dengan mengupayakan adanya lembaga upaya paksa dalam sistem eksekusi putusan Peradilan Tata Usaha Negara sebagaimana yang termaktub dalam Undang-Undang Nomor 9 Tahun 2004 Tentang Perubahan Atas Undang-Undang Nomor 5 Tahun 1986 Tentang Peradilan Tata Usaha Negara menimbulkan harapan akan adanya efektifitas penegak Hukum Adminitrasi Materil oleh Peradilan Tata Usaha Negara guna mewujudkan perlindungan hukum dari tindakan-tindakan pemerintah yang merugikan warga masyarakat.

Dalam eksekusi Putusan Pengadilan Tata Usaha Negara dengan mengandalkan upaya paksa tidak semua dapat dilaksanakan pada semua sengketa Tata Usaha Negara. Upaya paksa hanya dapat dilaksanakan pada amar putusan yang berisi diktum untuk menghukum tergugat menetapkan sebuah kewajiban sebagai pihak yang dikalahkan untuk bertindak mencabut dan menerbitkan Keputusan Tata Usaha Negara ataupun menerbitkan Keputusan Tata Usaha Negara dalam hal gugatan didasarkan pada Pasal 3 Undang-Undang Nomor 5 Tahun 1986 Tentang Peradilan Tata Usaha Negara. Sehingga tidak memberikan peluang pada jenis putusan lain untuk dilaksanakan eksekusi. 
Sifat eksekusi apabila dicermati secara seksama pada Pasal 116 ayat (4) jo ayat (5) Undang-Undang Nomor 9 Tahun 2004 Tentang Peradilan Tata Usaha Negara, maka akan didapatkan pengenaan upaya paksa yang bersifat imperatif. Dalam arti kata, sifat imperatifnya tersebut memerlukan 2 (dua) syarat yaitu :

1. Apabila sudah adanya permohonan dari penggugat kepada Ketua Pengadilan memerintahkan tergugat melaksanakan putusan Pengadilan, dan

2. Adanya perintah yang tidak dilaksanakan oleh tergugat oleh sebab tergugat tidak mau secara sukarela melaksanakan putusan Pengadilan. Sehingga apabila 2 (dua) syarat tersebut sudah memenuhi syarat, maka pengenaan upaya paksa berupa Uang Paksa (Dwangsom/Arbireinte) dan/atau sanksi administratif dan publikasi putusan pengadilan dapat dilaksanakan.

\section{Upaya Hukum Dalam Pengadilan Pada Badan Peradilan Lainnya.}

Upaya hukum yang ditempuh oleh para pencari keadilan (iustitibelen) pada pengadilan dalam peradilan lainnya tidak lain merupakan upaya terakhir apabila segala upaya yang ditempuh dalam eksekusi seperti yang tercantum dalam Pasal 116 Undang-Undang Nomor 9 Tahun 2004 Tentang Perubahan Atas Undang-Undang Nomor 5 Tahun 1986 Tentang Peradilan Tata Usaha Negara mengalami jalan hambatan. Jalan hambatan tersebut diperoleh dari tergugat sendiri yang merasa tidak mau secara sukarela melaksanakan putusan maupun telah ditempuh upaya paksa dalam Pasal 116 Undang-Undang Nomor 9 Tahun 2004 Tentang Perubahan Atas Undang-Undang Nomor 5 Tahun 1986 Tentang Peradilan Tata Usaha Negara tersebut seperti uang paksa dan/atau sanksi administratif dan publikasi putusan pengadilan pada media massa setempat.

Salah satu jalan keluar yang ditawarkan untuk pemecahan masalah ini dengan melakukan gugatan perdata atas perbuatan melanggar hukum (Pasal $1365 \mathrm{BW}$ ) yang dilakukan oleh pejabat pemerintah termasuk pejabat di daerah sebagai akibat tidak mematuhi putusan Badan/Pejabat Peradilan Tata Usaha Negara. Hal ini sebagai akibat kedudukan antara penggugat (orang/badan hukum perdata) dengan tergugat selaku penguasa tidaklah seimbang. Sehingga tergugat yang merasa mempunyai wewenang publik melakukan tindakan tidak menghormati putusan Badan/Pejabat Peradilan Tata Usaha Negara dibandingkan dengan putusan pada badan peradilan lainnya. Meskipun dalam kenyataannya putusan Badan/Pejabat Peradilan Tata Usaha Negara sebagai lembaga control yuridis ada yang dipatuhi dan ada yang tidak dipatuhi, tetapi lebih banyak yang tidak dipatuhi karena kurang efektif. Kurangnya keefektifan putusan pengadilan masih bervariasi tiap-tiap daerah. Bahkan yang menjadi perdebatan publik hingga kini adalah sikap pejabat pemerintah di daerah yang tidak lagi mempunyai hierarkis dalam otonomi daerah. Sehingga secara formil pejabat pemerintah patuh terhadap perintah Hakim Peradilan Tata Usaha Negara tetapi secara esensi tidak patuh.

Selain itu solusi yang ditawarkan oleh para ahli hukum menghadapi problematika ketidakpatuhan pejabat pemerintah di daerah yang tidak mematuhi putusan Badan Peradilan Tata Usaha Negara dengan mengajukan tuntutan pidana.

\section{PENUTUP}

\section{Simpulan}

Proses penyelesaian sengketa Tata Usaha Negara yang merupakan sengketa publik yang melibatkan orang/badan hukum perdata selaku penggugat dan pejabat pemerintah (Pejabat TUN) selaku tergugat, kekuatan hukum putusan eksekusi pengadilan Tata Usaha Negara yang merupakan pelaksana Kekuasaan Kehakiman di lingkungan Mahkamah Agung setara dengan keputusan pada badan peradilan lainnya. Adanya daya paksa dalam eksekusi putusan Pengadilan Tata Usaha Negara menjadikan Peradilan Tata Usaha Negara sederajat dengan badan peradilan lainnya yang terlebih dahulu telah mempunyai upaya pelaksanaan putusan secara paksa. Meskipun eksekusi di Peradilan Tata Usaha Negara sangat berbeda dengan eksekusi peradilan lainnya yang menitikberatkan pada eksekusi secara fisik. Kemudian perubahan normatif Peradilan Tata Usaha Negara dengan Undang-Undang Nomor 9 Tahun 2004 Tentang Perubahan Atas Undang-Undang Nomor 5 Tahun 1986 Tentang Peradilan Tata Usaha Negara menjadikan upaya hukum yang terdapat dalam Pasal 116 seperti uang paksa dan/atau sanksi administratif dan publikasi putusan pengadilan menjadi lebih baik ketimbang menggunakan model eksekusi secara hierarkis yang dianggap tidak efektif dengan adanya era otonomi daerah sekarang. Dengan keadaan tersebut masih harus diupayakan memberikan alternatif lain untuk menghasilkan efek jera bagi pejabat pemerintah khususnya pejabat pemerintah daerah untuk tunduk pada Putusan Pengadilan Tata Usaha Negara. 


\section{Saran}

Upaya hukum seperti uang paksa dan/atau sanksi administratif dan publikasi putusan pengadilan menjadi lebih baik ketimbang menggunakan model eksekusi secara hierarkis yang dianggap tidak efektif dengan adanya era otonomi daerah. Harus ada sanki untuk menghasilkan efek jera bagi pejabat pemerintah supaya tunduk pada Putusan Pengadilan Tata Usaha Negara.

\section{DAFTAR PUSTAKA}

H.M. Laica Marzuki. (2003). "Permasalahan Benturan Kewenangan Dalam Otonomi Daerah dan Penyelesaian Justisionalnya”. Makalah Pembanding Dalam Diskusi Temu Ilmiah memperingati HUT XII PERATUN. Bandung.

Paulus Effendi Lotulung. (1993). Beberapa Sistem Tentang Kontrol Segi Hukum Terhadap Pemerintahan (Edisi Ke II dengan Revisi). PT Citra Aditya Bakti: Bandung.

Peraturan Pemerintah Nomor 43 Tahun 1991 Tentang Ganti Rugi dan Tata Cara Pelaksanaannya.

Philipus M. Hadjon dkk. (2005). Pengantar Hukum Administrasi Indonesia. Cet Ke-9, Gadjah Mada Press: Yogyakarta

S. F. Marbun. (1997). Peradilan Administrasi Dan Upaya Administratif Di Indonesia. Liberty: Yogyakarta

S.F. Marbun. (2003). Peradilan Tata Usaha Negara. Liberty: Yogyakarta.

Supandi. (2004). Kepatuhan Hukum Pejabat Dalam Mentaati Putusan Tata Usaha Negara Di Medan, Disertasi Program Pasca Sarjana Ilmu Hukum. Universitas Sumatra Utara: Medan.

Tjahya Supriana. Sistem Administrasi di Daerah. Bumi Aksara, Jakarta.

Undang-Undang Dasar 1945.

Undang-Undang Nomor 12 Tahun 2008 Tentang Perubahan Kedua Undang-Undang Nomor 32 Tahun 2004 Tentang Pemerintahan Daerah. LN. RI Tahun 2008 Nomor 59. TLN Nomor 4844.

Undang-Undang Nomor 48 Tahun 2009 Tentang Kekuasaan Kehakiman. LN. RI Tahun 2009 Nomor 157. TLN. RI Nomor 5076.

Undang-Undang Nomor 51 Tahun 2009 Tentang Perubahan Atas Undang-Undang Nomor 5 Tahun 1986 Tentang Peradilan Tata Usaha Negara. LN. RI Tahun 2009 Nomor 160. TLN Nomor 5079.

Yahya Harahap. (1997). Beberapa Tinjauan Mengenai Sistem Peradilan dan Penyelesaian Sengketa. Cet. Pertama. Citra Aditya: Bandung. 